\title{
CDK9 Gene
}

National Cancer Institute

\section{Source}

National Cancer Institute. CDK9 Gene. NCI Thesaurus. Code C126980.

This gene plays a role in cyclin-dependent phosphorylation of protein substrates. 